\title{
Phylogenetic relationships of Chanidae (Teleostei: Gonorynchiformes) as impacted by Dastilbe moraesi, from the Sanfranciscana basin, Early Cretaceous of Brazil
}

\author{
Alexandre C. Ribeiro ${ }^{1}$, Francisco J. Poyato-Ariza ${ }^{2}$, Flávio A. Bockmann ${ }^{3}$ \\ and Marcelo R. de Carvalho ${ }^{4}$
}

Fossil gonorynchiform fishes range from the Lower Cretaceous to the early Miocene, and are represented by a few dozen living species. The order is currently divided into two major clades: Gonorynchoidei, which includes the families Gonorynchidae and Kneriidae, and Chanoidei, encompassing a single family, Chanidae, with a single recent species, the Indo-Pacific Chanos chanos, and several fossil taxa. Chanidae includes some poorly known taxa, such as Dastilbe moraesi, described from the Aptian (Lower Cretaceous) of the Areado Formation, Sanfranciscana basin, Brazil. This species is currently considered to be a junior synonym of the type species of its genus, Dastilbe crandalli, from Santana Formation, Aptian, northeastern Brazil. The analysis of abundant $D$. moraesi specimens revealed several new morphological features, many of which had previously been misinterpreted. Dastilbe moraesi was incorporated into a gonorynchiform character matrix as revised and modified for the Chanidae. We obtained a single most parsimonious tree in which $D$. moraesi is distinct and phylogenetically apart from $D$. crandalli. According our analysis, D. moraesi forms a sister pair with Chanos, a clade which is closely related to Tharrhias, all composing the tribe Chanini.

Keywords: Areado Formation, Fossil fishes, Marizal Formation, Phylogeny, Santana Formation.

Gonorynchiformes fósseis ocorrem desde do Cretáceo inferior ao Mioceno inferior, e são representados por alguns representantes viventes. A ordem está dividida atualmente em dois clados principais: Gonorynchoidei, que inclui as famílias Gonorynchidae e Kneriidae, e Chanoidei, compreendendo uma única família, Chanidae, com uma única espécie vivente, Chanos chanos, do Indo-Pacífico, além de vários representantes fósseis. Chanidae inclui alguns táxons problemáticos, tais como Dastilbe moraesi, descrito do Aptiano (Cretáceo Inferior) da Formação Areado, bacia Sanfranciscana, Brasil. Esta espécie é atualmente considerada um sinônimo júnior da espécie-tipo de seu gênero, Dastilbe crandalli, da Formação Santana, Aptiano do nordeste do Brasil. A análise de abundante material de D. moraesi revelou várias novas características anatômicas, muitas das quais haviam sido previamente mal interpretadas. Dastilbe moraesi foi incorporado em uma matriz revisada de caracteres da família Chanidae. Nós obtivemos uma única árvore mais parcimoniosa na qual $D$. moraesi é distinto e filogeneticamente distante de $D$. crandalli. De acordo com nossa análise, D. moraesi é o grupo-irmão de Chanos, um clado intimamente relacionado a Tharrhias, com todos compondo a tribo Chanini.

Palavras-chave: Filogenia, Formação Areado, Formação Marizal, Formação Santana, Peixes fósseis.

\section{Introduction}

Gonorynchiforms have a rich fossil record ranging from the earliest Cretaceous (Barriasian-Valanginian) to the earliest Miocene (Fara et al., 2010), and include several extant representatives. The order is divided into two main clades: suborder Gonorynchoidei, which includes the families Gonorynchidae and Kneriidae, and suborder Chanoidei, with a single family, Chanidae (Poyato-Ariza et al., 2010).

\footnotetext{
${ }^{1}$ Departamento de Biologia e Zoologia, Universidade Federal de Mato Grosso, Av. Fernando Corrêa da Costa, $\mathrm{n}^{\circ} 2367,78060-900$ Boa Esperança, Cuiabá, MT, Brazil. alexandrecunharibeiro@gmail.com, @ $h$ https://orcid.org/000-0001-7313-9562 (corresponding author)

${ }^{2}$ Centre for Integration on Palaeobiology \& Unidad de Paleontología, Departamento de Biología, Universidad Autónoma de Madrid, Cantoblanco, E-28049, Madrid, Spain. francisco.poyato@uam.es

${ }^{3}$ Laboratório de Ictiologia de Ribeirão Preto, Departamento de Biologia, FFCLRP, Universidade de São Paulo, Av. Bandeirantes 3900 , 14040-901 Ribeirão Preto, SP, Brazil; and Programa de Pós-Graduação em Biologia Comparada, FFCLRP, Universidade de São Paulo, Av. Bandeirantes 3900, 14040-901 Ribeirão Preto, SP, Brazil. fabockmann@ffclrp.usp.br

${ }^{4}$ Researcher currently not affiliated. New York, USA.gogolia99@gmail.com
} 
The Chanidae, with a single extant species, the IndoPacific milkfish Chanos chanos, and several fossil taxa, is a well distinguished clade, diagnosed on the basis of several synapomorphies such as: presence of a large, very broad, concave-convex premaxilla with a long oral process; enlarged maxilla with a posteriorly swollen to a bulbous outline and a curved posterior border; presence of a notch in the anterodorsal border of the dentary; quadrate-mandibular articulation anteriorly displaced and located anterior to the orbit by displacement of the quadrate bone and correlated elongation of the symplectic; metapterygoid process of hyomandibular present, placed on anterior border of the bone; opercular bone expanded, at least one-third of head length; angle formed by preopercular limbs straight to acute; preopercular expansion present (except in Dastilbe); suprapreopercular bone present as a relatively large, flat bone; and the presence of unmodified neural arches anterior to dorsal fin autogenous in adults individuals, at least laterally (Poyato-Ariza et al., 2010).

The genus Dastilbe Jordan, 1910, the main scope of this study, is currently assigned to the gonorynchiform suborder Chanoidei, family Chanidae (Grande, Poyato-Ariza, 1999). The genus Dastilbe was erected by Jordan (1910) for its type species Dastilbe crandalli Jordan, 1910, from the black shales of the Aptian of Riacho Doce (Lower Cretaceous), State of Alagoas, Brazil. Currently, four available names are recognized for Dastilbe, namely: its type species Dastilbe crandalli Jordan, 1910 from Riacho Doce, Alagoas, Brazil, D. elongatus Silva Santos, 1947 from Crato member, Santana Formation, Brazil, D. moraesi Silva Santos, 1955 from Areado Formation, Sanfranciscana basin, Brazil, and D. batai Gayet, 1989 from the Lower Cretaceous of Equatorial Guinea. Recently, Nanaichthys Amaral, Brito, 2012, a new genus, has been erected for a new species from the Marizal Formation (Early Cretaceous) of the Tucano Basin, Northeastern Brazil (Amaral, Brito, 2012), which had been informally referred to as "Dastilbe minor" (Silva Santos, 1972).

Despite being a well-defined clade, Chanidae still includes some problematical taxa, in relation to having an undetermined phylogenetic position and concerning the specific taxonomic composition of some genera, such as Dastilbe (Poyato-Ariza et al., 2010). Dastilbe, in particular, presents a complicated taxonomic situation. At present, according to Poyato-Ariza et al.(2010), the real problem of the genus Dastilbe is the uncertainty of its specific composition and the purportedly variation of its characters. The taxonomy of Dastilbe is far from being solved inasmuch as its species are poorly characterized and the differences among them are said to be very slightly (Poyato-Ariza, 1996a).

The original description of Dastilbe crandalli by Jordan (1910) is little informative and quite inaccurate, and its illustrations are of poor quality, being therefore of limited utility for its distinction from the species described subsequently. Silva Santos (1947) provided no diagnostic character for Dastilbe elongatus, except for the vague mention that its vertebral count is distinct from that of Dastilbe crandalli. Davis, Martill (1999) mentioned that the different localities and preservational environments probably led Silva Santos (1947) to distinguish Dastilbe elongatus from Dastilbe crandalli. However, there is no reference to these criteria in that Silva Santos's paper (1947), direct or indirect.

Silva Santos (1955) mentioned that Dastilbe moraesi may be separated from its congeners by a combination of characters, but none of them are actually distinctive, either in separate or in combination. Taverne (1981) mentioned that all nominal species, including Dastilbe moraesi, are junior synonyms of a single species, the type of the genus, Dastilbe crandalli. However, his suggestion lacks any factual evidence since no material of Dastilbe moraesi had been examined. In revising species of Dastilbe from the Santana Formation, northeastern Brazil, Blum (1991a) argued for the existence of two sympatric species in the Crato member, northeastern Brazil, which were previously identified as Dastilbe elongatus. He proposed to apply the epithets elongatus and crandalli to the larger and smaller specimens, respectively. Nothing was said about the distinction of these species from Dastilbe moraesi. Poyato-Ariza (1996a) cast doubts on the criteria used by Blum (1991a) - differences in body size and meristics to distinguish specimens of Dastilbe crandalli and D. elongatus from the Crato member, stating that there is a single species in that geological unit, which would be Dastilbe elongatus. In addition, Poyato-Ariza (1996a) suggested that the specimens of Dastilbe crandalli from Riacho Doce, State of Alagoas, its type locality, were not co-specific with small specimens of Dastilbe from the Crato member, differing in details of caudal skeleton. Indeed, Poyato-Ariza (1996a) was also the first author to explicitly distinguish Dastilbe moraesi from the other species of Dastilbe on the basis of peculiar traits of the mandibule, preopercle, and caudal skeleton. However, he warned that the validity of Dastilbe moraesi on the basis of these features depended on further investigation because he analyzed a single, imperfectly preserved specimen.

Davis, Martill (1999) carried out a comprehensive investigation about the taxonomy of Dastilbe, concluding that all diagnostic features reported so far to distinguish Dastilbe batai, Dastilbe crandalli, and Dastilbe elongatus, i.e., size, meristics, fin positions, and details of caudal skeleton, are within the range of variation of a unique, highly plastic species, which would be Dastilbe crandalli. Davis, Martill's (1999) opinion on the validity of Dastilbe moraesi is controversial. The characters thought to be diagnostic for Dastilbe moraesi by Poyato-Ariza (1996a) were refuted by Davis, Martill (1999), who asserted that “... no criteria have been found to satisfactorily define more than one species of Dastilbe". On the other hand, Davis, Martill (1999) do not reject Dastilbe moraesi as a valid species, but note that further studies are required. Their contention may be explained by the fact that no specimen of Dastilbe 
moraesi had been examined. Grande, Poyato-Ariza (1999) retained Dastilbe moraesi as a valid species, although these authors studied the same specimen examined by PoyatoAriza (1996a).

Recently, Amaral, Brito (2005) proposed to redescribe Dastilbe from Gondwana but no data were offered regarding the validity of its species. Ribeiro et al. (2005), on the basis of newly collected material, re-examined the status of Dastilbe moraesi and supported it as valid. Dietze (2007) agreed that Dastilbe elongatus is a junior synonym of the type species but argued that Dastilbe moraesi is too poorly known to arrive at any conclusion in this respect. Finally, Brito, Amaral (2008) concluded that, due to the high plasticity of the characters, it is impossible to distinguish any nominal species from the type species. However, as pointed out by Poyato-Ariza et al. (2010), none of these studies conducted a re-examination of type material of any nominal species of this genus, which is, according to these authors, an indispensable requirement to achieve more definitive taxonomic conclusions.

Based on the analysis of primary types of Dastilbe moraesi and Dastilbe elongatus (a junior synonym of Dastilbe crandalli) (Figs. 1 and 2; see examined material), as well as abundant additional material of $D$. moraesi recently collected in the type locality during two field trips (in 2005 and 2011), we were able to perform a detailed morphological reanalysis of Dastilbe moraesi in order to define its status and phylogenetic position.

\section{Material and Methods}

Examined specimens are from the following institutions: Academy of Natural Sciences of Drexel University, Philadelphia (ANSP); American Museum of Natural History, New York (AMNH); Coleção de Peixes da Universidade Federal de Mato Grosso, Mato Grosso, Brazil (CPUFMT); Divisão de Museu de Ciências da Terra, Departamento Nacional de Produção Mineral, Rio de Janeiro, Brazil (DGM); Instituto de Geociências, Universidade Federal do Rio de Janeiro, Brazil (UFRJ); and Laboratório de Ictiologia de Ribeirão Preto, Universidade de São Paulo, São Paulo, Brazil (LIRP);

Recently collected specimens from the Sanfranciscana basin were prepared mechanically with needles under the stereomicroscope. Museum specimens from Araripe basin were acid and mechanically prepared, following the methods of Toombs, Rixon (1959). Photos were taken with a digital camera (Motican 2500) attached to a SMZ 800 Nikon stereomicroscope. Drawings were made using a camera lucida attached to a SMZ 800 Nikon stereomicroscope as well as from digital photographs. Anatomical nomenclature follows Poyato-Ariza et al. (2010). Standard length (SL) refers to the traditional standard length, measured from snout tip to caudal peduncle at origin of caudal fin. Total fragment length (TFL) refers to the total fossil fragment length, when it is only partially preserved.

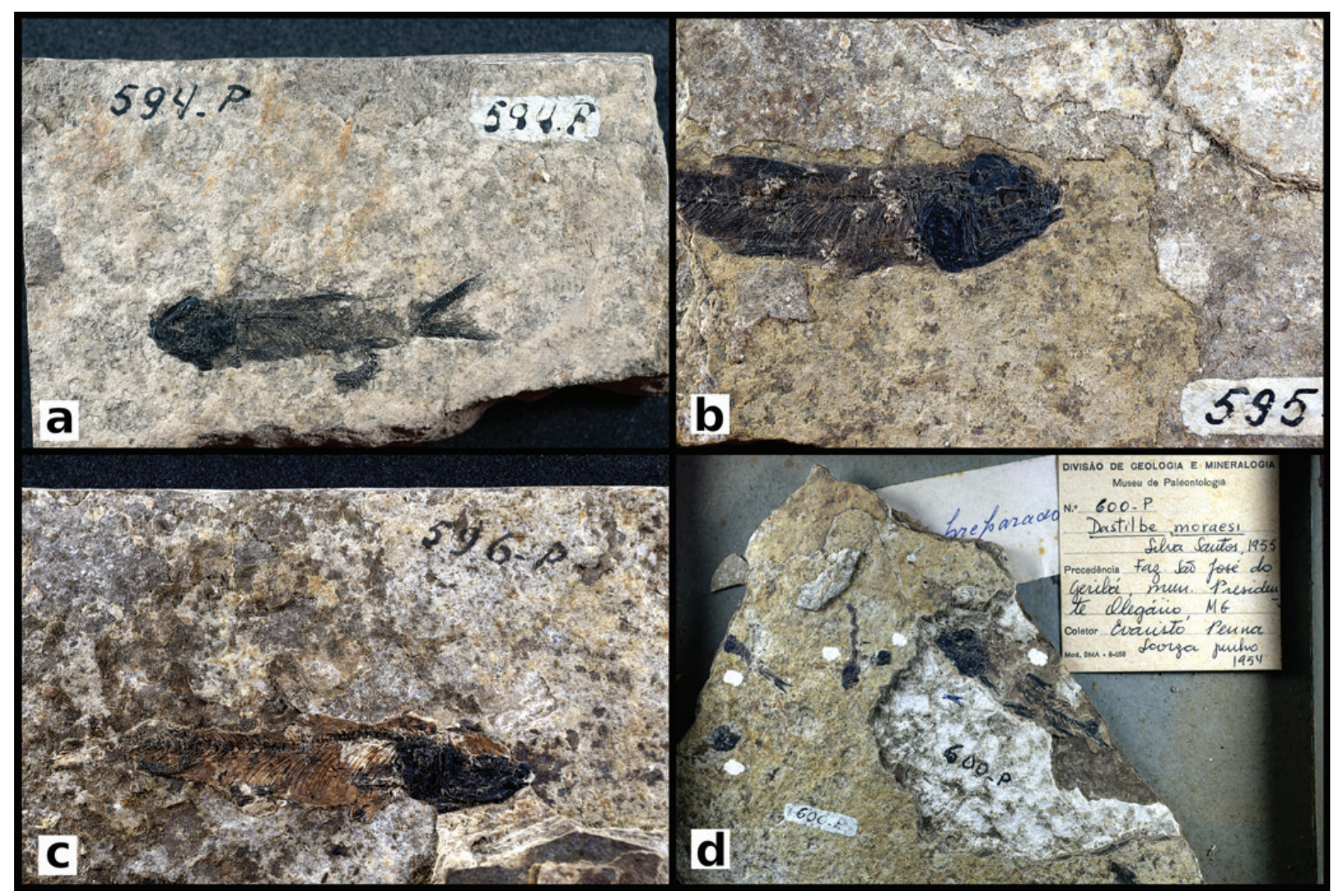

Fig. 1. Paratypes of Dastilbe moraesi: a. DGM 594P, $33.7 \mathrm{~mm}$ SL, anterior to left; b. DGM 595P, 39.2 mm TFL, anterior to right; c. DGM 596P (larger specimen), $58.0 \mathrm{~mm} \mathrm{SL}$, anterior to rigth; and d. DGM 600P (larger specimen), $58 \mathrm{~mm} \mathrm{SL}$, anterior to left. 

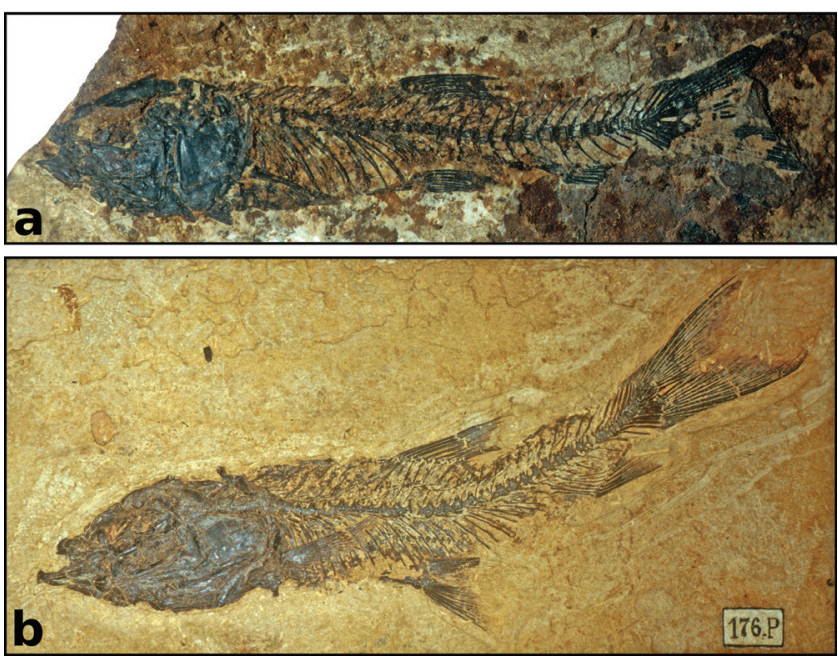

Fig. 2. a. Dastilbe moraesi, DGM 593-P, $47.0 \mathrm{~mm}$ SL, holotype, Fazenda São José do Geribá, Presidente Olegário, State of Minas Gerais, Brazil; b. Dastilbe crandalli, DGM 176-P, $153.6 \mathrm{~mm}$ SL, holotype of Dastilbe elongatus, Brazil, State of Ceará, Sítio Romualdo, $15 \mathrm{~km}$ from Crato, coll. C. G. Gomes, August 1934.

Most of the 106 characters used in the present analysis (Tab. 1, S1) were revised from Poyato-Ariza et al. (2010). They were polarized by using a compound outgroup as explained in that article. In order to keep track, the numbers in the data matrix from that article are indicated below in brackets after their actual number in the present list.

Only osteological characters were used. Myological characters (i.e., characters 112-130 in Poyato-Ariza et al., 2010) were not used herein because they cannot be coded for fossil forms and do not alter the topology of the relationships among the Gonorynchiformes based on osteological characters only (Poyato-Ariza et al., 2010: 305).

Because the present analyses is focused on the Chanidae, only Gonorynchus and Kneria are included. All chanid taxa pointed out as problematic by Poyato-Ariza et al. (2010) were removed from the analyses, including Erfoudichthys rosae (Pittet et al., 2010), referred to as "New Genus" in Poyato-Ariza et al. (2010), Apulichthys and Sorbininardus. Some characters from Poyato-Ariza et al. (2010) are not used here, since they are invariant in the chanid genera and provide no information for the interrelationships among them. Characters entirely removed from the data matrix of Poyato-Ariza et al. (2010) because they are not present in the ingroup taxa of the present analysis are (numbers as in that paper): $33,54,62,66,73,105,109$, and 112130. Character states removed are 8(2), 9(3), 18(3), 35(2), $36(2), 37(2), 41$ (1 and 3; former state 2 is now 1), 60(3), 63(2), 69(2), 70 (1 and 3; former state 2 is now 1), 77(2), 78(2), 84(2), 91(2), 94(2), and 102(2). For simplification and clarity, characters 83, 85, 96, 102, and 107 in PoyatoAriza et al. (2010) have been redefined, and character 97 (94 in the list below) has been entirely revised and recoded for all taxa.
Characters 29 and 30 in the list below were not used in the analysis by Poyato-Ariza et al. (2010) because their codings were problematic within Gonorynchidae. However, since they are relevant for the Chanidae, they are included in our analyses. They are revised from characters 11 and 12 in Poyato-Ariza (1996a). Character 35 below is new.

Concerning Nanaichthys, all characters were coded as in Amaral, Brito (2012: tab. 1), except when we were able to reinterpret a character based on the illustrations and photographs presented in their paper (this is particularly relevant in the reinterpretation and character coding proposed by us regarding the morphology of the premaxilla and maxilla in Nanaichthys, Fig. 3); the new characters were coded based on the information (description and illustrations) provided in Amaral, Brito (2012) (see specific comments in the character list below). Characters of the remaining terminal taxa were coded exactly as in PoyatoAriza et al. (2010), except when indicated.

Phylogenetic analysis was performed in TNT (Goloboff et al., 2008) using the "New Technology Search" option in the default settings. Multi-state characters were treated as unordered.

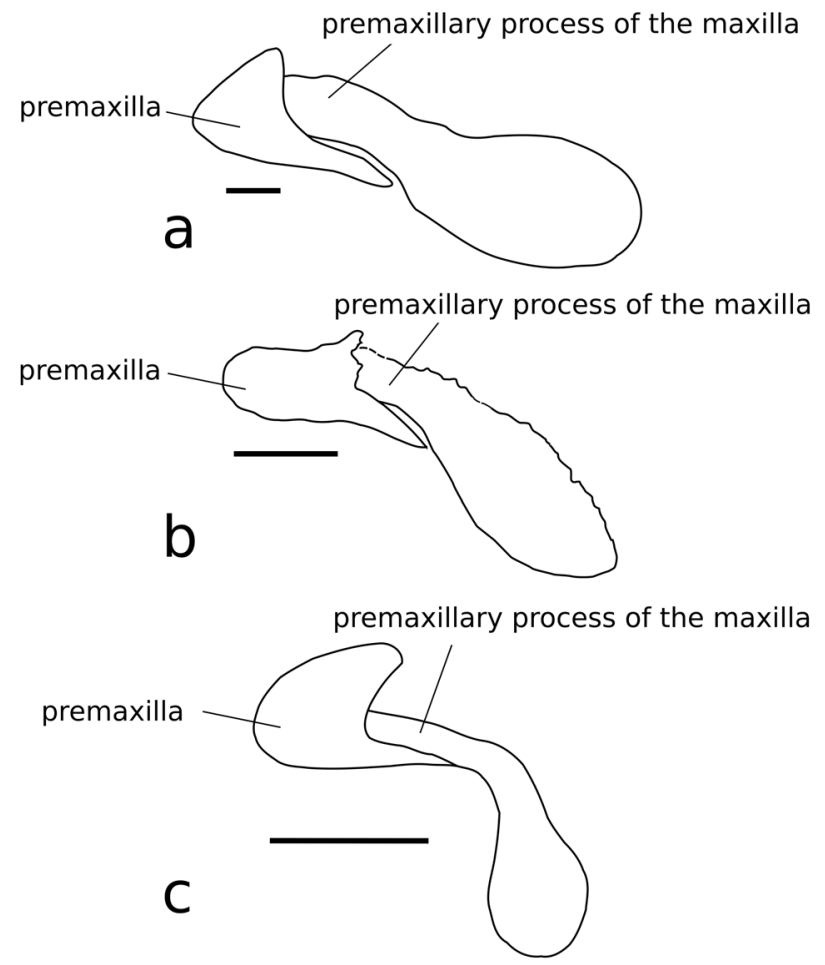

Fig. 3. Outlines of the premaxilla and the maxilla in three chanid genera in order to compare the relative length and curvature of the premaxillary process of the maxilla in: a. Dastilbe elongatus, based mostly on specimens AMNH 31 and AMNH 12721 (redrawn from Poyato-Ariza, 1996a, figs. 2A and 7); b. Nanaichthys longipinnus, based on the holotype, DGM.1016-P (redrawn from Amaral, Brito, 2012, fig. 4C); and c. Rubiesichthys gregalis, based on the restoration of the skull from numerous specimens (redrawn from Poyato-Ariza, 1996b, fig. 2). All left side, lateral view. Scale bars $=1 \mathrm{~mm}$. 
Tab. 1. Data matrix for 14 taxa and 106 characters used in the present phylogenetic study, revised from Poyato-Ariza et al. (2010) (S1). Original character numbers in the data matrix from that article are indicated in brackets.

\begin{tabular}{|c|c|c|c|c|c|c|c|c|c|c|c|c|c|c|c|c|c|c|c|c|}
\hline $\begin{array}{l}\text { Present Character } \\
\text { (previous number) }\end{array}$ & $\begin{array}{c}1 \\
(1)\end{array}$ & $\begin{array}{c}2 \\
(2)\end{array}$ & $\begin{array}{c}3 \\
(3) \\
\end{array}$ & $\begin{array}{c}4 \\
(4) \\
\end{array}$ & $\begin{array}{c}5 \\
(5) \\
\end{array}$ & $\begin{array}{c}6 \\
(6) \\
\end{array}$ & $\begin{array}{c}7 \\
(16) \\
\end{array}$ & $\begin{array}{c}8 \\
(17) \\
\end{array}$ & $\begin{array}{c}9 \\
(7) \\
\end{array}$ & $\begin{array}{c}10 \\
(18)\end{array}$ & $\begin{array}{c}11 \\
(19)\end{array}$ & $\begin{array}{l}12 \\
(8) \\
\end{array}$ & $\begin{array}{l}13 \\
(9) \\
\end{array}$ & $\begin{array}{r}14 \\
(10 \\
\end{array}$ & $\begin{array}{c}15 \\
(11) \\
\end{array}$ & $\begin{array}{c}16 \\
(12) \\
\end{array}$ & $\begin{array}{c}17 \\
(13)\end{array}$ & $\begin{array}{c}18 \\
(14) \\
\end{array}$ & $\begin{array}{c}19 \\
(15) \\
\end{array}$ & $\begin{array}{c}20 \\
(68) \\
\end{array}$ \\
\hline Diplomystus & 0 & 0 & 0 & 0 & $?$ & 0 & 0 & 0 & 0 & 0 & 0 & 0 & 0 & 0 & 0 & 0 & 0 & 0 & 0 & 0 \\
\hline Brycon & 0 & 1 & 0 & 0 & 0 & 0 & 0 & 0 & 0 & 0 & 0 & 1 & 0 & 1 & 0 & 0 & 2 & 0 & 0 & 0 \\
\hline Opsariichthys & 0 & 1 & 0 & 0 & 0 & 0 & 0 & 0 & 0 & 0 & 0 & 1 & 0 & 0 & 0 & 0 & 0 & 0 & 0 & 0 \\
\hline$\dagger$ Aethalionopsis & $?$ & $?$ & $?$ & $?$ & $?$ & $?$ & 0 & $?$ & $?$ & 0 & $?$ & $?$ & 0 & 0 & 0 & $?$ & 2 & 1 & 1 & 0 \\
\hline Chanos & 1 & 1 & 1 & 1 & 1 & 2 & 1 & 0 & 0 & 2 & 0 & 1 & 0 & 0 & 0 & 0 & 2 & 0 & 2 & 1 \\
\hline$\dagger$ Dastilbe & 1 & 1 & 1 & 0 & 0 & $?$ & 1 & 0 & $?$ & 0 & $?$ & $?$ & 0 & 0 & 0 & 0 & 2 & 0 & 1 & $?$ \\
\hline Gonorynchus & 1 & 1 & 2 & 0 & 0 & 1 & 0 & 0 & 1 & 0 & 0 & 1 & 1 & 0 & 1 & 1 & 2 & 0 & 1 & 2 \\
\hline$\dagger$ Gordichthys & 1 & 1 & $?$ & 0 & $?$ & $?$ & 0 & $?$ & $?$ & 0 & $?$ & 0 & 0 & 0 & 0 & 0 & 1 & 0 & 1 & $?$ \\
\hline Kneria & 1 & 1 & 2 & 0 & 0 & 1 & 0 & 1 & 0 & 1 & 1 & 0 & 0 & 0 & 0 & 0 & 2 & 0 & 3 & 1 \\
\hline$\dagger$ Parachanos & $?$ & $?$ & $?$ & 0 & $?$ & $?$ & $?$ & $?$ & $?$ & 0 & $?$ & 1 & 0 & 0 & 0 & 0 & 2 & 0 & 1 & $?$ \\
\hline$\dagger$ Rubiesichthys & 1 & 1 & $?$ & 0 & $?$ & $?$ & 0 & $?$ & $?$ & 0 & $?$ & 0 & 0 & 0 & 0 & 0 & 2 & 0 & 1 & $?$ \\
\hline$\dagger$ Tharrhias & 1 & 1 & 1 & 0 & 1 & $?$ & 1 & 0 & 0 & 2 & $?$ & 1 & 0 & 0 & 0 & 0 & 2 & 0 & 1 & 1 \\
\hline$\dagger$ Nanaichthys & $?$ & $?$ & $?$ & $?$ & $?$ & $?$ & 0 & $?$ & 0 & $?$ & 0 & $?$ & 0 & 0 & 0 & 0 & 2 & $?$ & $?$ & $?$ \\
\hline$\dagger$ Dastilbe moraesi & 1 & 1 & 2 & 1 & 1 & 1 & 1 & $?$ & $?$ & 2 & 1 & 1 & 0 & 0 & 0 & $?$ & 2 & 1 & 1 & $?$ \\
\hline $\begin{array}{l}\text { Present Character } \\
\text { (previous number) }\end{array}$ & $\begin{array}{c}21 \\
(69)\end{array}$ & $\begin{array}{c}22 \\
(70)\end{array}$ & $\begin{array}{c}23 \\
(71)\end{array}$ & $\begin{array}{c}24 \\
(20)\end{array}$ & $\begin{array}{c}25 \\
(21)\end{array}$ & $\begin{array}{c}26 \\
(22)\end{array}$ & $\begin{array}{c}27 \\
(23)\end{array}$ & $\begin{array}{c}28 \\
(24)\end{array}$ & 29 & 30 & $\begin{array}{c}31 \\
(25)\end{array}$ & $\begin{array}{c}32 \\
(26)\end{array}$ & $\begin{array}{c}33 \\
(27) \\
\end{array}$ & $\begin{array}{c}34 \\
(28)\end{array}$ & 35 & $\begin{array}{c}36 \\
(29)\end{array}$ & $\begin{array}{c}\mathbf{3 7} \\
\mathbf{( 3 0 )}\end{array}$ & $\begin{array}{c}38 \\
(31) \\
\end{array}$ & $\begin{array}{c}39 \\
(32) \\
\end{array}$ & $\begin{array}{c}40 \\
(39) \\
\end{array}$ \\
\hline †Diplomystus & 0 & 0 & $?$ & 0 & 0 & 0 & 0 & 0 & 0 & 0 & 0 & 0 & 0 & 0 & 0 & 0 & 0 & 0 & 0 & 0 \\
\hline Brycon & 0 & 0 & 0 & 0 & 0 & 0 & 0 & 0 & 0 & 0 & 0 & 0 & 0 & 1 & 0 & 0 & 0 & 0 & 0 & 1 \\
\hline Opsariichthys & 0 & 0 & 0 & 1 & 0 & 0 & 0 & 0 & 0 & 0 & 0 & 0 & 0 & 1 & 0 & 0 & 0 & 0 & 0 & 1 \\
\hline$\dagger$ Aethalionopsis & 0 & 0 & 0 & 1 & 0 & $?$ & 1 & $?$ & 1 & 0 & 0 & 1 & 1 & 1 & 0 & 0 & 0 & $?$ & 0 & $?$ \\
\hline Chanos & 0 & 0 & 0 & 1 & 0 & 0 & 1 & 1 & 1 & 1 & 0 & 1 & 1 & 1 & 1 & 0 & 0 & 1 & 0 & 1 \\
\hline$\dagger$ Dastilbe & 0 & 0 & 0 & 1 & 0 & $?$ & 1 & 1 & 1 & 2 & 0 & 1 & 1 & 1 & 1 & 0 & 0 & 1 & 0 & 1 \\
\hline Gonorynchus & 1 & 2 & 1 & 1 & 1 & 1 & 0 & 1 & 1 & 2 & 0 & 0 & 0 & 1 & 0 & 1 & 1 & 0 & 1 & 1 \\
\hline$\dagger$ Gordichthys & 0 & 0 & 0 & 1 & 0 & $?$ & 1 & 1 & 0 & 2 & 1 & 0 & 1 & 1 & 0 & 0 & 0 & 1 & 0 & 1 \\
\hline Kneria & 1 & 0 & 0 & 1 & 0 & 0 & 0 & 1 & 2 & 0 & 0 & 1 & 0 & 1 & 1 & 1 & 0 & 0 & 1 & 1 \\
\hline$\dagger$ Parachanos & 0 & 0 & 0 & 1 & 0 & $?$ & 1 & 1 & 1 & 1 & 0 & 1 & 1 & 1 & 0 & 0 & 0 & $?$ & 0 & $?$ \\
\hline$\dagger$ Rubiesichthys & 0 & 0 & 0 & 1 & 0 & $?$ & 1 & 1 & 0 & 2 & 1 & 0 & 1 & 1 & 0 & 0 & 0 & 1 & 0 & 1 \\
\hline$\dagger$ Tharrhias & 0 & 0 & 0 & 1 & 0 & $?$ & 1 & 1 & 1 & 1 & 0 & 1 & 1 & 1 & 1 & 0 & 0 & 1 & 0 & 1 \\
\hline$\uparrow$ Nanaichthys & $?$ & 0 & 0 & 1 & 0 & $?$ & 1 & 1 & 1 & 1 & 0 & 1 & 1 & 1 & 0 & 0 & 0 & $?$ & 0 & 1 \\
\hline$\dagger$ Dastilbe moraesi & $?$ & $?$ & 1 & 1 & 0 & 0 & 1 & 1 & 1 & 1 & 0 & 1 & 1 & 1 & 0 & 0 & 0 & $?$ & 0 & $?$ \\
\hline $\begin{array}{l}\text { Present Character } \\
\text { (previous number) }\end{array}$ & $\begin{array}{c}41 \\
(40) \\
\end{array}$ & $\begin{array}{c}42 \\
(41) \\
\end{array}$ & $\begin{array}{c}43 \\
(42) \\
\end{array}$ & $\begin{array}{c}44 \\
(43) \\
\end{array}$ & $\begin{array}{c}45 \\
(44) \\
\end{array}$ & $\begin{array}{c}46 \\
(38) \\
\end{array}$ & $\begin{array}{c}47 \\
(34) \\
\end{array}$ & $\begin{array}{c}48 \\
(35) \\
\end{array}$ & $\begin{array}{c}49 \\
(36) \\
\end{array}$ & $\begin{array}{c}\mathbf{5 0} \\
(37) \\
\end{array}$ & $\begin{array}{c}51 \\
(45) \\
\end{array}$ & $\begin{array}{c}52 \\
(46) \\
\end{array}$ & $\begin{array}{c}53 \\
(47) \\
\end{array}$ & $\begin{array}{c}54 \\
(52) \\
\end{array}$ & $\begin{array}{r}55 \\
(53) \\
\end{array}$ & $\begin{array}{c}56 \\
(55) \\
\end{array}$ & $\begin{array}{c}57 \\
(56) \\
\end{array}$ & $\begin{array}{c}\mathbf{5 8} \\
(\mathbf{5 7}) \\
\end{array}$ & $\begin{array}{c}59 \\
(58) \\
\end{array}$ & $\begin{array}{r}60 \\
(59) \\
\end{array}$ \\
\hline$\dagger$ Diplomystus & 0 & 0 & 0 & 0 & 0 & 0 & 0 & 0 & 0 & 0 & 0 & 0 & $?$ & 0 & 0 & 0 & 0 & 0 & 0 & 0 \\
\hline Brycon & 0 & 0 & 0 & 0 & 0 & 0 & 0 & 0 & 0 & 0 & 0 & 0 & 0 & 0 & 0 & 0 & 0 & 0 & 0 & 0 \\
\hline Opsariichthys & 0 & 0 & 0 & 0 & 0 & 0 & 0 & 0 & 0 & 0 & 0 & 0 & 0 & 0 & 0 & 0 & 0 & 0 & 0 & 0 \\
\hline$\dagger$ Aethalionopsis & 0 & 0 & $?$ & $?$ & $?$ & 0 & 0 & 1 & 1 & 0 & 0 & $?$ & $?$ & 1 & 0 & 0 & $?$ & 1 & 0 & 1 \\
\hline Chanos & 0 & 0 & 0 & 0 & 2 & 0 & 0 & 1 & 1 & 1 & 0 & 1 & 0 & 1 & 0 & 0 & 0 & 1 & 0 & 0 \\
\hline$\dagger$ Dastilbe & 0 & 0 & $?$ & $?$ & $?$ & 0 & 0 & 1 & 1 & 0 & 0 & 1 & $?$ & 1 & 0 & 0 & $?$ & 1 & 0 & 1 \\
\hline Gonorynchus & 1 & 2 & 0 & 0 & 1 & 1 & 0 & 0 & 0 & 0 & 1 & 0 & 0 & 0 & 1 & 0 & 1 & 0 & 0 & 0 \\
\hline$\dagger$ Gordichthys & 0 & 0 & 1 & $?$ & $?$ & 0 & 0 & 1 & 1 & 0 & 0 & 1 & $?$ & 1 & 0 & 0 & $?$ & 2 & 0 & 0 \\
\hline Kneria & 0 & 2 & 0 & 1 & 2 & 0 & 0 & 0 & 0 & 0 & 1 & 2 & 0 & 0 & 0 & 1 & 1 & 0 & 0 & 0 \\
\hline$\dagger$ Parachanos & 0 & 0 & $?$ & $?$ & $?$ & 0 & 0 & 1 & 1 & 0 & 0 & 1 & $?$ & 1 & 0 & 0 & $?$ & 1 & 0 & 1 \\
\hline$\dagger$ Rubiesichthys & 0 & 0 & $?$ & $?$ & $?$ & 0 & 0 & 1 & 1 & 0 & 0 & 1 & $?$ & 1 & 0 & 0 & $?$ & 2 & 0 & 0 \\
\hline$\dagger$ Tharrhias & 0 & 0 & 0 & 0 & 2 & 0 & 0 & 1 & 1 & 1 & 0 & 1 & $?$ & 1 & 0 & 0 & $?$ & 1 & 0 & 1 \\
\hline$\dagger$ Nanaichthys & 0 & $?$ & 0 & $?$ & $?$ & 0 & 0 & 1 & 1 & 0 & 0 & 1 & $?$ & 1 & 0 & 0 & $?$ & 0 & 0 & 1 \\
\hline$\dagger$ Dastilbe moraesi & 0 & 0 & 0 & $?$ & $?$ & 0 & 0 & 1 & 1 & 0 & 0 & 1 & $?$ & 1 & 0 & 0 & $?$ & 0 & 0 & 1 \\
\hline
\end{tabular}


Tab. 1. (continued).

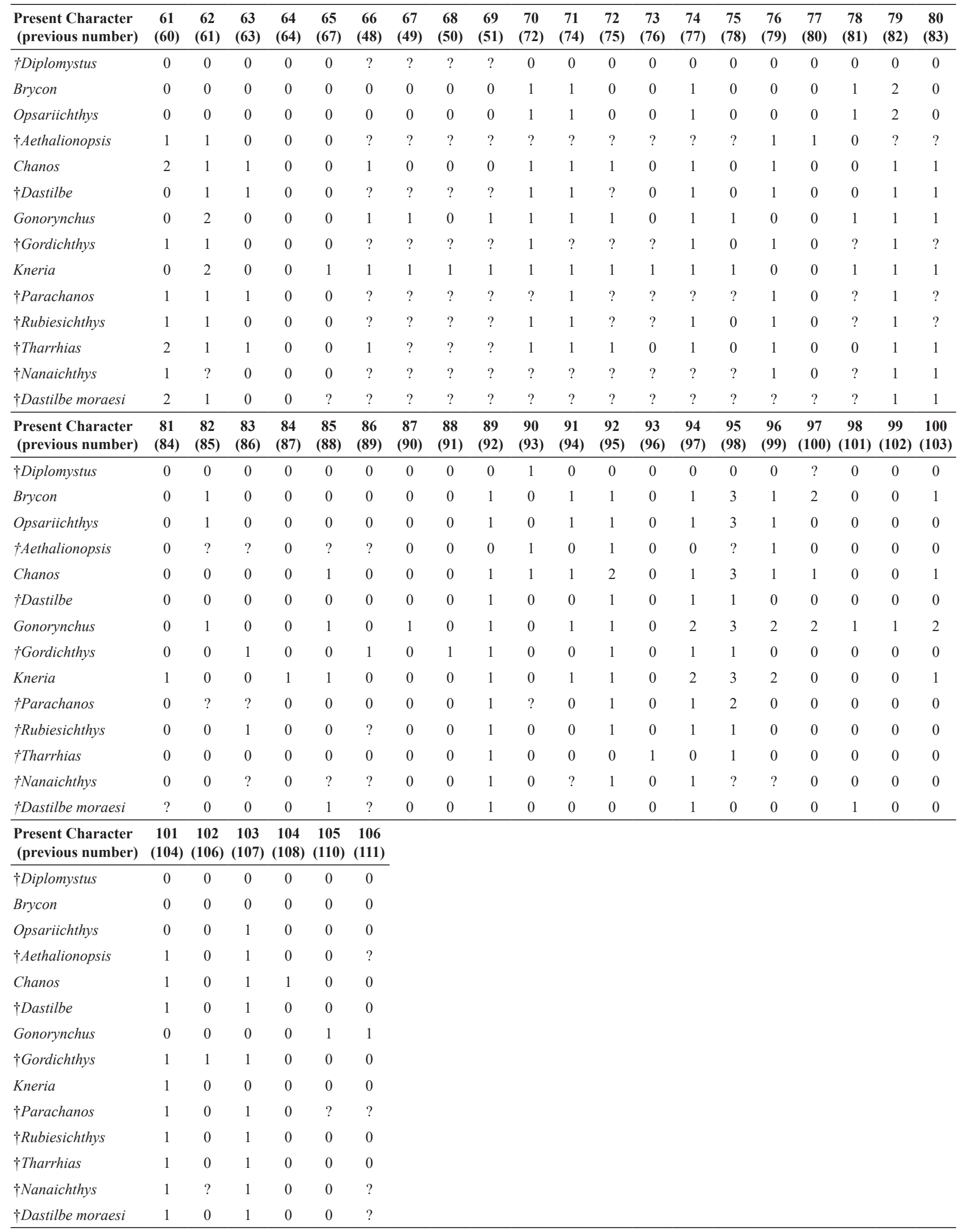




\section{Results}

The phylogenetic analysis resulted in a single most parsimonious tree $(\mathrm{CI}=0.743 ; \mathrm{RI}=0.733 ; 166$ steps long; Fig. 4; see $\mathbf{S 2}$ ).

According to our results, the inclusion of Dastilbe moraesi in the Gonorynchiformes (Node 2) is uncontroversial, as indicated by the presence of cephalic ribs (C.6:1), parietals reduced and separated by the supraoccipital (C.17:1), and absence of the premaxillary ascending process (C.28:1) (Fig. 5). It is also a member of the Chanoidei, as indicated by the presence of a large, very broad, concave-convex premaxilla, with a long oral process (C.27:1), the presence of a maxilla posteriorly swollen to a bulbous outline (C.33:1), quadrate-mandibular articulation anteriorly displaced (anterior to the orbit) (C.48:1), symplectic elongated (C.49:1), metapterygoid process of hyomandibular present on its anterior border (C.52:1) (Fig. $6)$, opercular bone expanded to at least one third of head length (C.54:1), and suprapreopercular bone present as a relatively large, flat bone (C.62:1) (Fig. 7).

The inclusion of $D$. moraesi in the Chanidae (Node 4) is supported by several synapomorphies, such as: presence of a large, very broad, concave-convex premaxilla with a long oral process (C.27:1); the posterior region of the maxilla very enlarged, swollen and having a bulbous outline, with curved posterior border (C.33:1); quadratemandibular articulation located anterior to orbit, with the quadrate displaced but not elongate (C.48:1); presence of an elongated symplectic (C.49:1); presence of a metapterygoid process of hyomandibula (C.52:1); presence of an expanded opercular bone, with at least one third of the head length (C.54:1); by having an preopercular expansion present on preopercle posteroventral corner and part of the posterodorsal limb (C.61:1); and the presence of autogenous hemal arch in preural centrum 2 (C.103:1).

Our analysis indicated that the Chanidae is divided in two clades: Rubiesichthys + Gordichthys (Node 5, subfamily Rubiesichthyinae), and Nanaichthys + (Aethalionopsis + (Parachanos + (Dastilbe + (Tharrhias + (Dastilbe moraesi + Chanos $)$ )))) (Node 6, subfamily Chaninae). The Node 5 is supported by three synapomorphies: dorsal and ventral borders of the maxillary articular process very curved (C.31:1); angle formed by preopercular limbs acute (C.58: 2); and posterior process on the posterior border of first supraneural present (C.83:1). The Node 6, in turn, is supported by the presence of a maxillary process for articulation with the autopalatine (C. 32:1), and by the presence of a ridge on the anteroventral limb of the preopercular bone (C.60:1).

Nanaichthys, according to our analysis, is the sistergroup of the clade formed by the remaining taxa included in Node 6, forming together the subfamily Chaninae.

Dastilbe crandalli is the sister-group of Chanini (including Tharrias, Dastilbe moraesi and Chanos) based on the presence of the anterodorsal border of the dentary slightly concave, forming a relatively high symphysis (C.35:1).

The inclusion of Dastilbe moraesi within the Chanini (including Tharrhias and Chanos) is based on the presence of exoccipitals with a posterior concave-convex border, with a projection above the basioccipital (C.5:1), a large mesethmoid with broad posterolateral wing-like expansions (C10:1), and the presence of a neural arch and spine of the first preural centrum both well developed, with the spine about half as long as preceding ones (C.92:1) (Fig. 8).
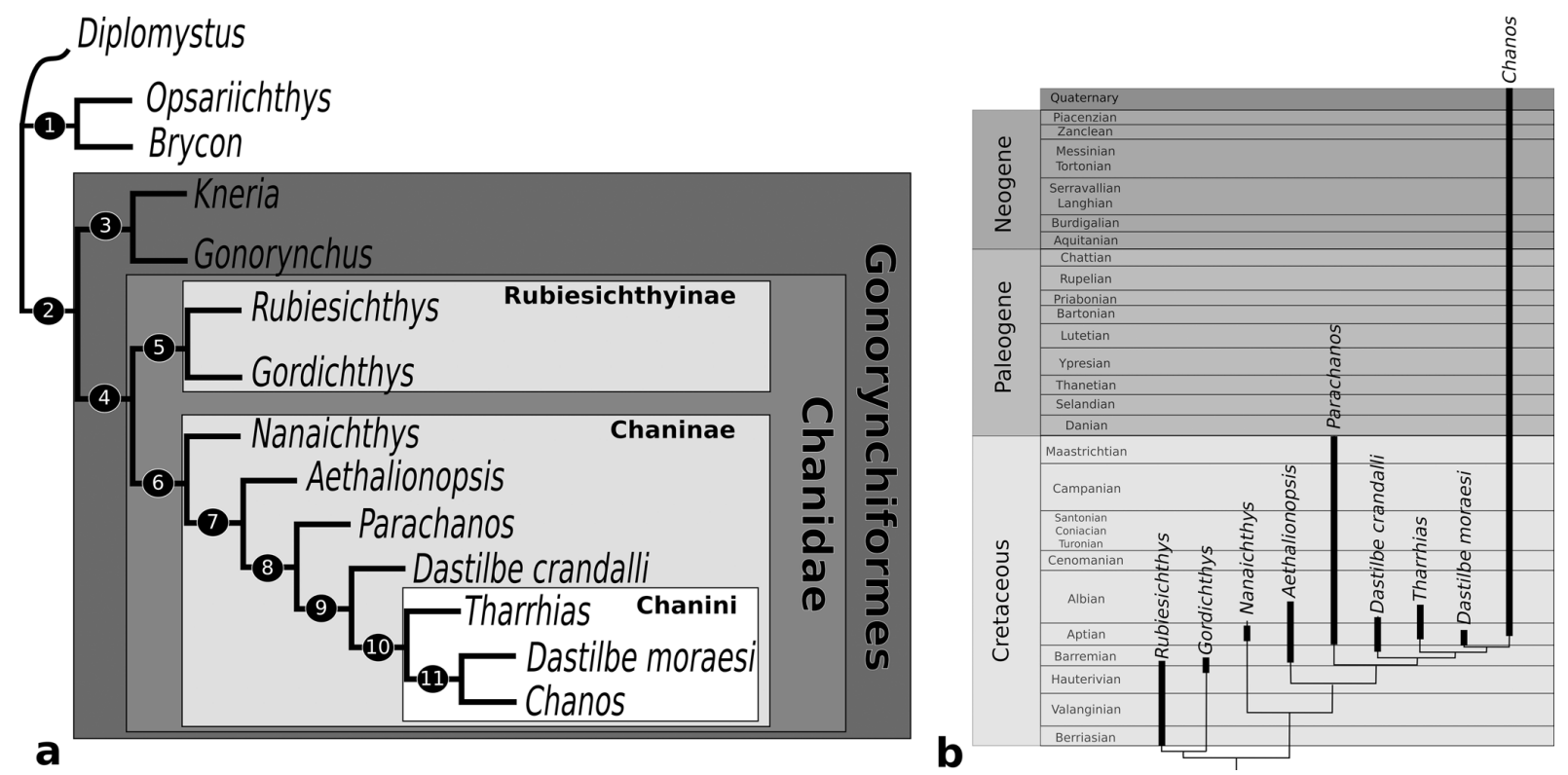

Fig. 4. a. Single most parsimonious tree $(\mathrm{CI}=0.743 ; \mathrm{RI}=0.733 ; 166$ steps long $)$ depicting phylogenetic relationships of Dastilbe moraesi and other chanids. Clades 1 to 11 are supported by synapomorphies described in S2; b. highlighted vertical branch length expresses the occurrence of taxa in the fossil record. 


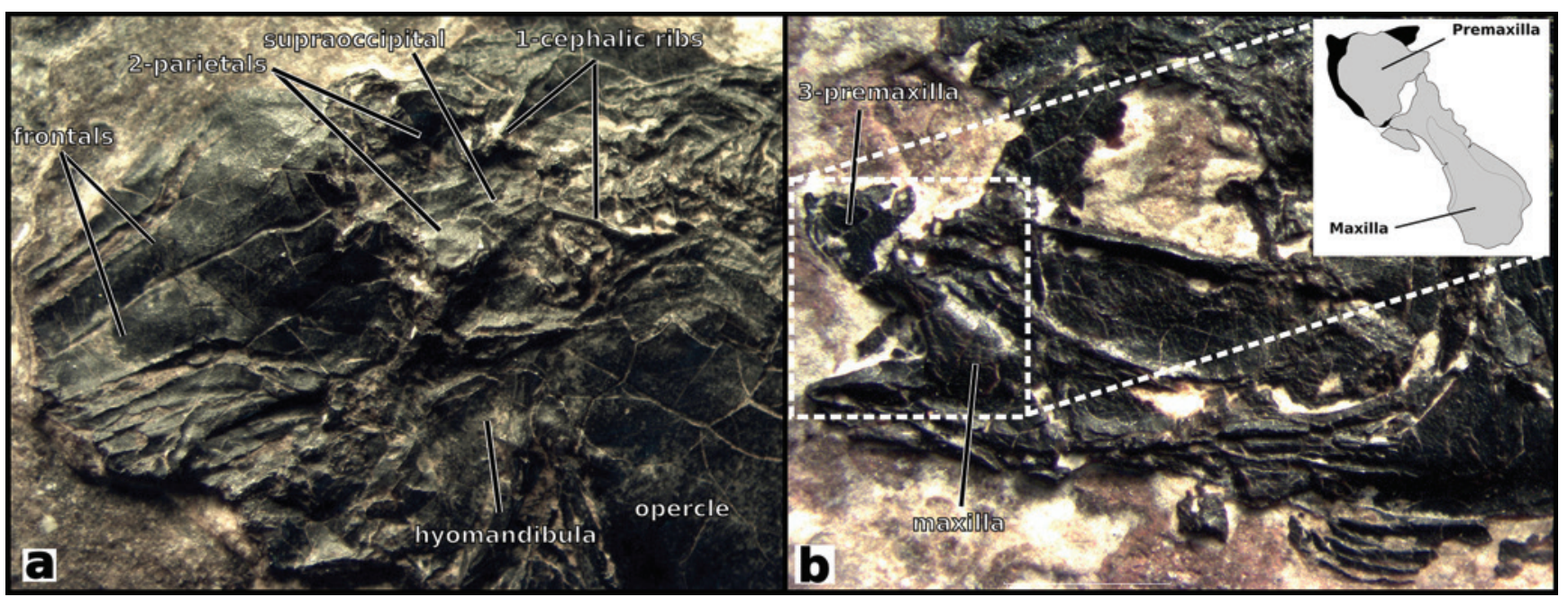

Fig. 5. a. Dastilbe moraesi (CPUFMT 5150, $16.0 \mathrm{~mm}$ TFL), anterior to left. b. Dastilbe moraesi (CPUFMT $730,30.0 \mathrm{~mm}$ TFL), anterior to left. Synapomorphies of Gonorynchiformes observed are: 1-cephalic ribs; 2- parietals reduced and separated by supraoccipital, 3- absence of premaxillary ascending process.

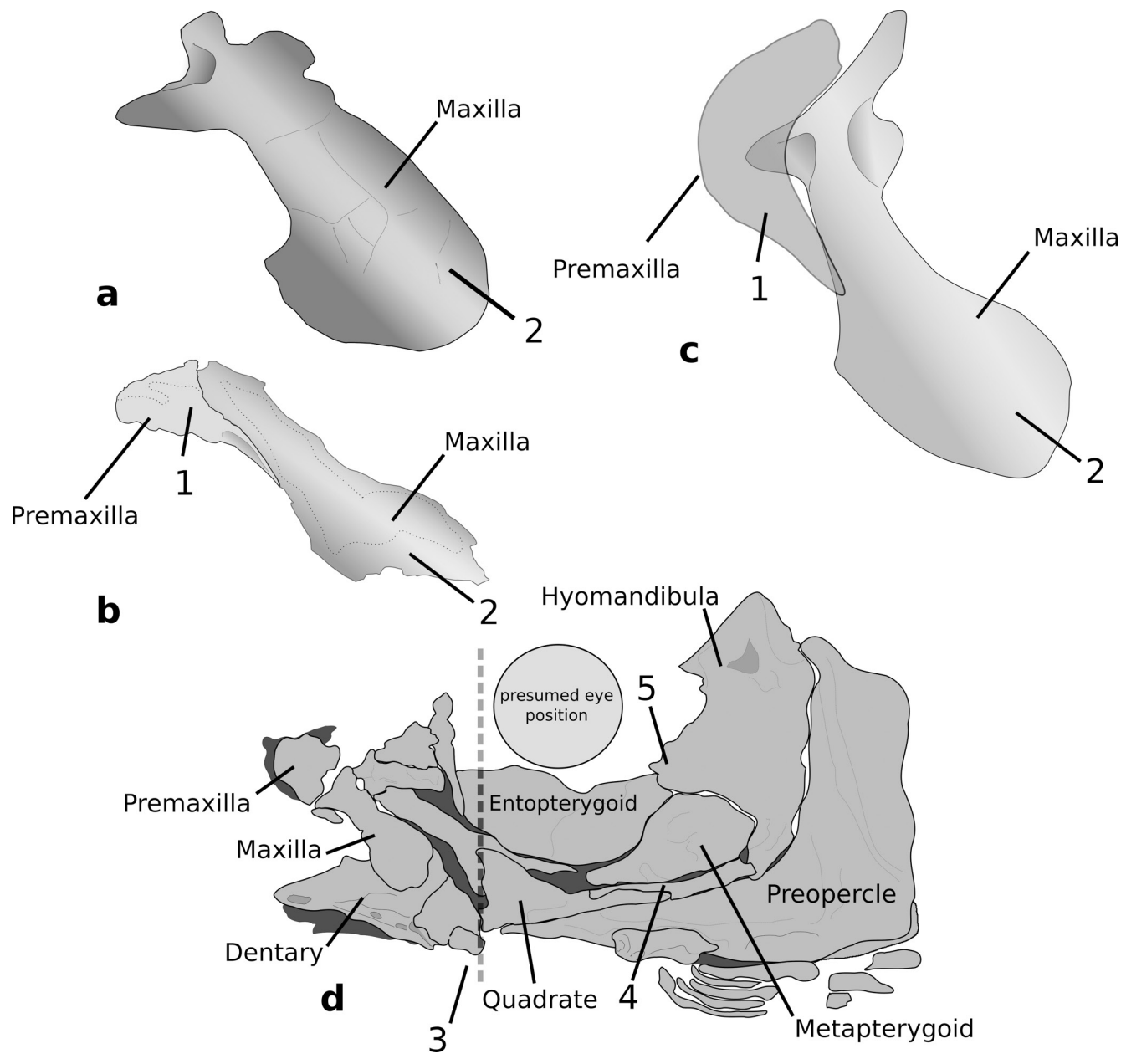

Fig. 6. a. Maxilla of Dastilbe moraesi (CPUFMT 734), lateral view, anterior to left; b. Maxilla and premaxilla of Dastilbe crandalli, uncatalogued specimen, lateral view, anterior to left; c. Maxilla and premaxilla of Chanos chanos, ANSP 63199, lateral view, anterior to left. d. Jaws and suspensorium of Dastilbe moraesi (CPUFMT 730, $30.0 \mathrm{~mm}$ TFL), lateral view, anterior to left. Synapomorphies of Chanoidei observed are: 1-Large, very broad, concave-convex premaxilla, with long oral process; 2- posterior region of the maxilla expanded in a bulbous outline; 3- quadrate-mandibular articulation anteriorly displaced, anterior to orbit; 4- symplectic elongated; 5- metapterygoid process of hyomandibula present on its anterior border. 


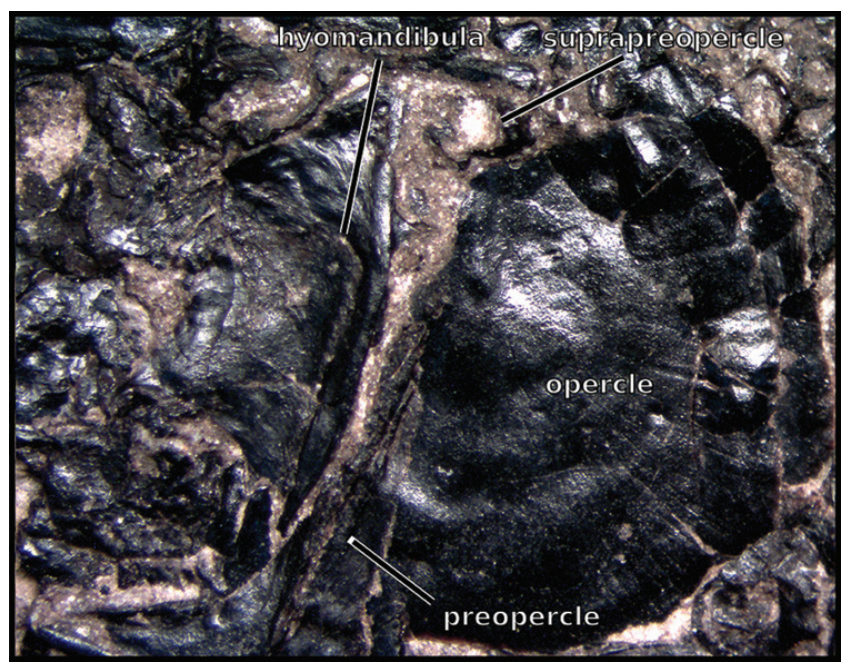

Fig. 7. Opercular region of Dastilbe moraesi (CPUFMT $745,16.3 \mathrm{~mm}$ TFL) in lateral view, anterior to left: Synapomorphies of Chanidae observed are: opercular bone is expanded, at least one-third of the head length; and suprapreopercular bone is present as a relatively large, flat bone.
The sister group relationship between Dastilbe moraesi and Chanos (Node 11) is supported by the presence of the posterolateral expansion of exoccipitals (C.4:1), and the absence of postcleithra (C.85:1). Dastilbe moraesi is phylogenetic diagnosed from the remaining Chanidae by the autapomorphic condition of its caudal-fin skeleton, characterized by the presence of only five hypurals (Fig. 9).

\section{Discussion}

Dastilbe moraesi, a small gonorynchiform fish from the Early Cretaceous of the Sanfranciscana basin in southeastern Brazil, has been considered one of the most obscure taxa previously assigned to the family Chanidae. Indeed, the lack of sufficient material was the main constraint toward reaching a more definitive conclusion regarding its phylogenetic affinities and taxonomic status. The analysis of abundant material from the type locality, Fazenda São José do Geribá, Presidente Olegário, Minas Gerais state, Brazil, filled this gap and provided vast material for observation of detailed morphological data as the quality of preservation of the material is outstanding.

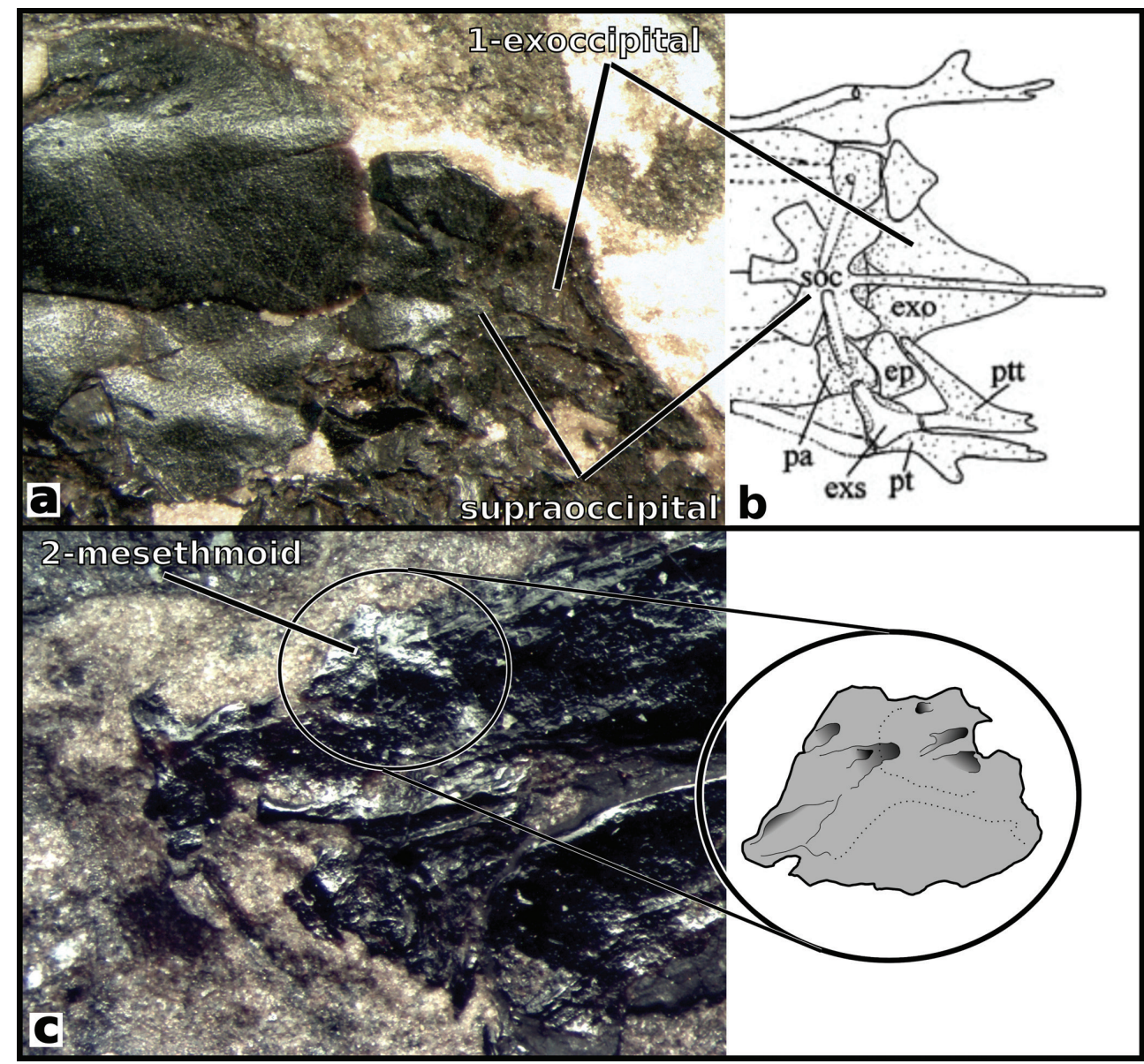

Fig. 8. a. Dorsal view of the posterior portion of skull in Dastilbe moraesi (CPUFMT 732.7 mm TFL) and b. Chanos chanos (modified from Poyato-Ariza et al., 2010). c. Dorsal view of the anterior portion of skull in Dastilbe moraesi (CPUFMT 735, $26.4 \mathrm{~mm} \mathrm{SL).} \mathrm{Synapomorphies} \mathrm{of} \mathrm{Chanini} \mathrm{observed} \mathrm{are:} \mathrm{1-} \mathrm{exoccipitals} \mathrm{with} \mathrm{a} \mathrm{posterior} \mathrm{concave-convex} \mathrm{border,} \mathrm{with} \mathrm{a}$ projection above basioccipital. 2- large mesethmoid, with broad posterolateral wing-like expansions. 


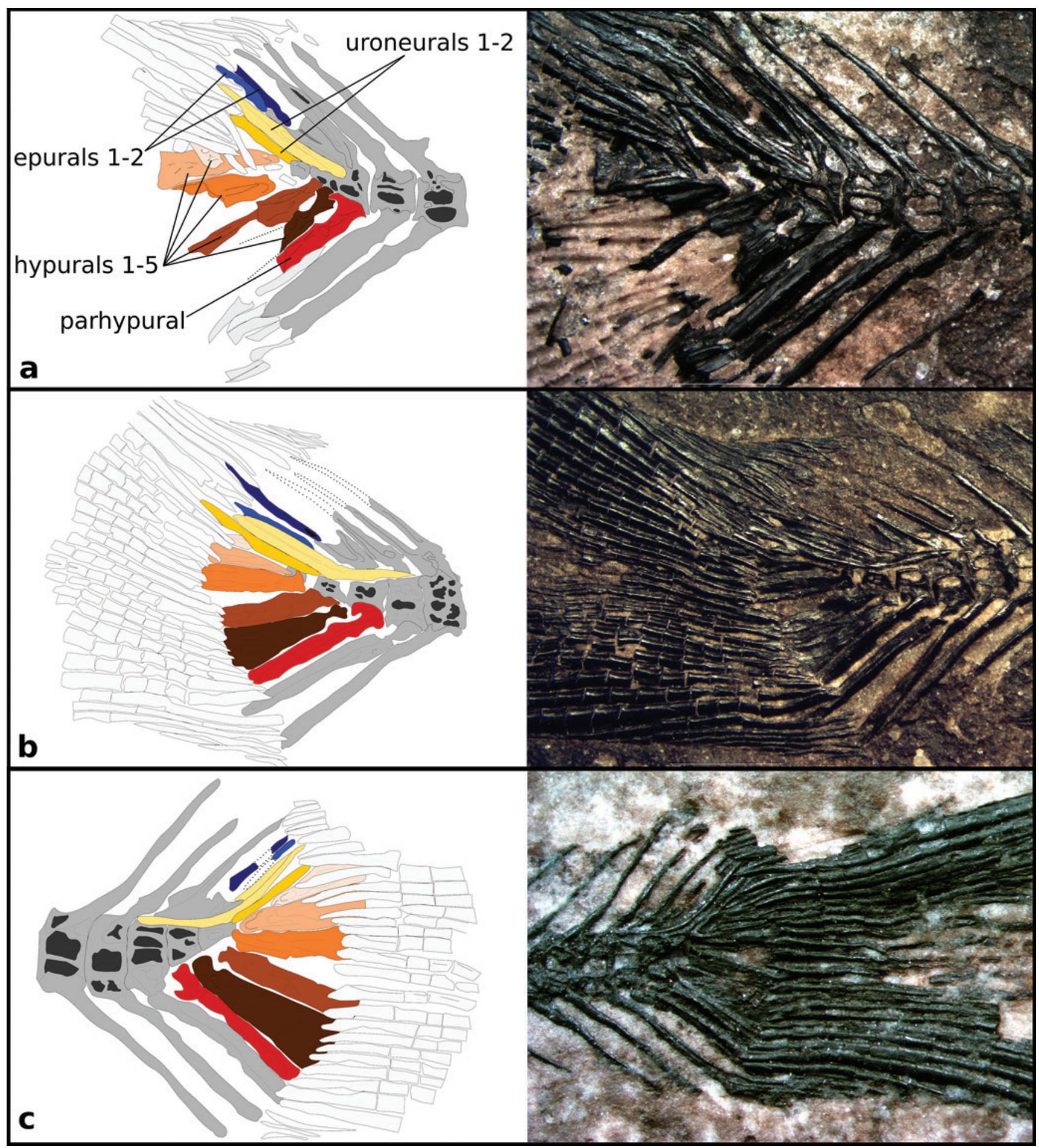

Fig. 9. Caudal-fin skeleton in Dastilbe moraesi as observed in: a. specimen CPUFMT 746, 28.0 mm TFL, anterior to right; b. specimen CPUFMT 736, $37.0 \mathrm{~mm}$ TFL, anterior to right and c. specimen CPUFMT 748, $21.0 \mathrm{~mm}$ TFL, anterior to left.

The resulting topology of our phylogenetic analysis differs significantly from previous, even recent, hypotheses of chanid relationships. We confirmed the sister-group relationships between Rubiesichthys and Gordichthys as previously proposed by Poyato-Ariza et al. (2010) (without the inclusion of Nanaichthys) and Amaral, Brito (2012) (which included Nanaichthys), a hypothesis supported by the presence of both the dorsal and ventral borders of the maxillary articular process very curved (C.31:1); the presence of a ventral metapterygoid process of hyomandibular (C.52:2); and the presence of a posterior process on the posterior border of first supraneural (C.83:1). However, the position of Nanaichthys as the sister-group of the Laurasian clade Rubiesichthys + Gordichthys 
(Amaral, Brito, 2012) was not supported herein. According to our results, Nanaichthys is more closely related to Aethalionopsis, Parachanos, Chanos, and the Brazilian fossil gonorynchiforms than it is to the Rubiesichthyinae (Gordichthys + Rubiesichthys). Some anatomical characters were either misinterpreted by those authors (e.g., numbers 30 and 32 herein) or assumed without enough evidence (e.g., numbers 62 and 75 herein). As a consequence, the complex palaeobiogeographical implications proposed by Amaral, Brito (2012), encompassing influences of the Caribbean Tethys, Mediterranean Tethys and Laurasia prior to the Aptian/Albian marine transgressions over the continental terrains of Western Gondwana, are not supported as well.

Concerning Aethalionopsis, our results are compatible with those presented by Poyato-Ariza et al. (2010), in which this genus is the sister-group of the clade formed by the remaining Chaninae, as supported in this study by the presence of an approximately straight angle formed by preopercular limbs (C.58:1). Parachanos, Dastilbe, and the clade Chanos + Tharrhias formed an apical polytomy within Chanidae in Poyato-Ariza et al. (2010) and Amaral, Brito (2012). In our analysis, Parachanos is the sister-group of the clade that includes Dastilbe crandalli $+($ Tharrhias $+($ Dastilbe moraesi + Chanos $))$, which (Node 9) is supported by the presence of a dentary symphysis higher than immediately posterior part of the dentary and robust (C.35:1).

Dastilbe moraesi is morphologically more similar to the living Chanos chanos than previously thought. In the present analysis, several new similarities shared between both taxa were observed, such as the very similar morphological aspect of the anterior maxillary process (Fig. 6). In both D. moraesi and Chanos chanos, for instance, the anterior portion of maxilla has characteristic processes which is very similar in position and degree of development. The number of processes in the anterior portion of the maxilla is not included as a distinct character because the condition is very difficult to be properly assessed in most fossil chanids, since the anteriormost part of the premaxillary process of the maxilla is covered by the premaxilla in lateral view, but it may constitute an additional character supporting the sister-group relationships between D. moraesi and Chanos. The same is true for the degree of posterior development of the exoccipitals (also shared by Tharrhias).

In conclusion, our results are interesting not only because it reveals that Dastilbe moraesi is a valid species, as previously proposed by Ribeiro et al. (2005), but also that it is not the sister group of $D$. crandalli (assuming that this species is a senior synonym of D. elongatus analyzed in this study). Significant individual variation within each species, as suggested by Davis, Martill (1999) and reiterated by Brito, Amaral (2008), was not confirmed in our study since all specimens of both $D$. crandalli and $D$. moraesi are found to be very conservative in their morphological and meristic diagnostic attributes. As for the nomenclature to reflect the topology obtained, it is necessary to erect a new genus for $D$. moraesi, which will be done in a forthcoming account in which the morphology of $D$. moraesi will be treated in greater detail.

Material examined. Types. Dastilbe moraesi, DGM 593-P, holotype, $47.0 \mathrm{~mm}$ SL, Fazenda São José do Geribá, município de Presidente Olegário, Minas Gerais, coll. L. J. de Moraes, 14 May 1954; Dastilbe moraesi, paratypes, DGM594-P, DGM595-P, DGM596-P, DGM600-P, DGM601-P, collected with the holotype; Dastilbe crandalli: DGM 176-P, syntype of Dastilbe elongatus, 153.6 mm SL, Brazil, Ceará, Sítio Romualdo, 15 km from Crato, coll. C. G. Gomes, Aug 1934. Non-types. Dastilbe moraesi, LIRP 5249-5275, collected in the type locality, coll. A. C. Ribeiro \& G. C. Ribeiro, 20 Mar 2005; CPUFMT 730-749; CPUFMT 1889; CPUFMT 5150, collected in the type locality, coll. A. C. Ribeiro \& G. C. Ribeiro, 1 Jan 2011. Dastilbe crandalli, UFRJ-DG-316-P, UFRJ-DG-380-P, UFRJ-DG-569-P，UFRJ-DG-581-P， Araripe Basin, Brazil. Chanos chanos, ANSP 63199, 1 ex., 156.6 mm SL, Philippines, W. Pacific, Orion, Bataan Province, Luzon, coll. Rev. J. Clemens, 29 Apr 1923; ANSP 63296, 2 ex., 154.8-159.8 mm SL, same locality and collector as ANSP 63199, 24 Apr 1923; ANSP 63299, 2 c\&s, 91.5-96.2 mm SL. Gonorynchus gonorynchus, ANSP 37748, 1 ex., 241.1 mm SL, Australia, Victoria, Melbourne, Indian Ocean, coll. A. F. Kenyon, 1909. Kneria auriculata, ANSP 177939, 1 ex. in isopropyl alcohol, $45.6 \mathrm{~mm} \mathrm{SL}, 1 \mathrm{c} \& s, 44.7 \mathrm{~mm}$ SL, Mozambique, 19²0’S 03256E, coll. O. Weyl, 25 Mar 1997.

\section{Acknowledgments}

We thank the organizing committee of the II International Symposium on Phylogeny and Classification of Neotropical Fishes for the invitation that led to the preparation of this manuscript. Orlando Ribeiro and Guilherme C. Ribeiro helped during the collection expeditions. We thank Diogenes A. Campos, Ismar S. Carvalho, John G. Maisey, and Mark H. Sabaj for allowing us to study material under their care and by loaning specimens. This study was supported by CNPq (process \# 401818/2010-1) and project CGL2013-42643P, Ministerio de Ciencia e Innovación de España.

\section{References}

Amaral CLR, Brito PM. Redescription of Dastilbe (Teleostei: Gonorynchiformes) from the Early Cretaceous of Western Gondwana. In: Poyato-Ariza FJ, editor. Fourth International Meeting on Mesozoic Fishes - Systematics, Homology, and Nomenclature. Miraflores de La Sierra, Madrid, Spain. August 8th-14th, 2005. Extended abstracts. Madrid: UAM Ediciones; 2005. p.21.

Amaral CRL, Brito PM. A new Chanidae (Ostariophysii: Gonorynchiformes) from the Cretaceous of Brazil with affinities to Laurasian gonorynchiforms from Spain. PLoS One [serial on the Internet]. 2012; 7(5):e37247 . Available from: https://doi.org/10.1371/journal.pone.0037247 
Blum S. Dastilbe Jordan, 1910. In: Maisey JG, editor. Santana Fossils: An Illustrated Atlas. Neptune City: T.F.H. Publications; 1991a. p 274-83.

Blum S. Tharrhias Jordan and Branner, 1908. In: Maisey JG, editor. Santana Fossils: An Illustrated Atlas. Neptune City: T.F.H. Publications; 1991b. p.286-96.

Brito PM, Amaral CRL. An overview of the specific problems of Dastilbe Jordan 1910 (Gonorynchiformes: Chanidae) from the Lower Cretaceous of western Gondwana. In: Arratia G, Schultze HP, Wilson MVH, editors. Mesozoic Fishes 4: Homology and Phylogeny. Munchen: Verlag Dr. Friedrich Pfeil; 2008. p.279-94.

Davis SP, Martill DM. The gonorynchiform fish Dastilbe from the Lower Cretaceous of Brazil. Palaeontology [serial on the Internet]. 1999; 42(4):715-40. Available from: https://doi. org/10.1111/1475-4983.00094

Dietze K. Redescription of Dastilbe crandalli (Chanidae, Euteleostei) from the Early Cretaceous Crato formation of northeastern Brazil. J Vert Paleontol [serial on the Internet]. 2007;27(1):8-16. Available from: https://doi.org/10.1671/02724634(2007)27[8:RODCCE]2.0.CO;2

Fara E, Gayet M, Taverne L. The fossil record of Gonorynchiformes. In: Grande T, Poyato-Ariza F, Diogo R, editors. Gonorynchiformes and Ostariophysan Relationships: A Comprehensive Review. Enfield (New Hampshire): Science Publishers; 2010. p.173-226.

Fink SV, Fink WL. Interrelationships of ostariophysan fishes. Zool J Linn Soc. 1981; 72:297-353.

Goloboff PA, Farris JS, Nixon KC. TNT, a free program for phylogenetic analysis. Cladistics [serial on the Internet]. 2008; 24(5):774-86. Available from: https://doi.org/10.1111/j.10960031.2008.00217.x

Grande T. Phylogeny and paedomorphosis in an African family of freshwater fishes (Gonorynchiformes: Kneriidae). Fieldiana Zool New Series. 1994; 78:1-20.

Grande T, Poyato-Ariza FJ. Phylogenetic relationships of fossil and Recent gonorynchiform fishes (Teleostei: Ostariophysi). Zool J Linn Soc [serial on the Internet]. 1999; 125(2):197-238. Available from: https://oi.org/10.1111/j.1096-3642.1999. tb00591.x

Jordan DS. Description of a collection of fossil fishes from the bituminous shales at Riacho Doce, State of Alagôas, Brazil Ann Carnegie Mus. 1910; 7(1):23-34.

Patterson C, Johnson GD. The intermuscular bones and ligaments of teleostean fishes. Smithson Contrib Zool. 1995; 559:1-83.

Pittet F, Cavin L, Poyato-Ariza FJ. A new teleostean fish from the early late Cretaceous (Cenomanian) of SE Morocco, with a discussion of its relationships with ostariophysans. In: Grande T, Poyato-Ariza F, Diogo R, editors. Gonorynchiformes and Ostariophysan Relationships: A Comprehensive Review. Enfield (New Hampshire): Science Publishers; 2010. p.339-62.

Poyato-Ariza FJ. A new Early Cretaceous gonorynchiform fish (Teleostei: Ostariophysi) from Las Hoyas (Cuenca, Spain). Occ Pap Mus Nat Hist Univ Kansas. 1994; 164:1-37.
Poyato-Ariza FJ. A revision of the ostariophysan fish family Chanidae, with special reference to the Mesozoic forms. Palaeo Ichthyol. 1996a; 6:5-52.

Poyato-Ariza FJ. A revision of Rubiesichthys gregalis Wenz 1984 (Ostariophysi, Gonorynchiformes), from the Early Cretaceous of Spain. In: Arratia G, Viohl G, editors. Mesozoic Fishes: Systematics and Palaeoecology. München: Verlag Dr. Friedrich Pfeil; 1996b. p.319-28.

Poyato-Ariza FJ, Grande T, Diogo R. Gonorynchiform interrelationships: historic overview, analysis, and revised systematics of the group. In: Grande T, Poyato-Ariza F, Diogo R, editors. Gonorynchiformes and Ostariophysan Relationships: A Comprehensive Review. Enfield (New Hampshire): Science Publishers; 2010. p.227-337.

Poyato-Ariza FJ, López-Horgue MA, García-Garmilla F. A new early Cretaceous clupeomorph fish from the Arratia Valley, Basque Country, Spain. Cretac Res [serial on the Internet]. 2000; 21(4):571-85. Available from: https://doi.org/10.1006/ cres. 2000.0212

Ribeiro AC, Bockmann FA, Carvalho MR. Revision of Dastilbe moraesi, Silva Santos, 1955 (Ostariophysi: Chanidae), a valid species from the Areado Formation, Early Cretaceous of Brazil. In: Poyato-Ariza, FJ, editor. Fourth International Meeting on Mesozoic Fishes - Systematics, Homology, and Nomenclature. Miraflores de La Sierra, Madrid, Spain. August 8th-14th, 2005. Extended abstracts. Madrid: UAM Ediciones; 2005. p.221-26.

Silva Santos R. Uma redescrição de Dastilbe elongatus, com algumas considerações sobre o gênero Dastilbe. Not Prel Est Min Agr Div Geol Min, DNPM. 1947; 42:1-7.

Silva Santos R. Descrição dos peixes fósseis. In: Scorza EP, Silva Santos R, editors. Ocorrência de folhelho fossilífero cretácico no Município de Presidente Olegário, Minas Gerais. Bol Div Geol Miner, DNPM. 1955; 155:17-27.

Silva Santos R. Peixes da Formação Marizal, Estado da Bahia [PhD Thesis]. São Paulo, SP: Instituto de Geociências da Universidade de São Paulo; 1972.

Taverne L. Ostéologie et position systématique d'Aethalionopsis robustus (Pisces, Teleostei) du Crétacé inférieur de Bernissart (Belgique) et considérations sur les affinités des Gonorynchiformes. Bull Acad R Belg Cl Sci. 1981; 67(5):95882.

Toombs HA, Rixon AE. The use of acids in the preparation of vertebrate fossils. Curator[serial on the Internet]. 1959;2(4):30412. Available from: https://doi.org/10.1111/j.2151-6952.1959. tb00514.x

Weitzman SH. The osteology of Brycon meeki, a generalized characid fish, with an osteological definition of the family. Stanford Ichthyol Bull. 1962; 8(1):3-77. 